\title{
Foraging behaviour and dry matter intake by lambs in a silvopastoral system
}

\section{Comportamiento de forrajeo y consumo de materia seca por ovinos en un sistema silvopastoril}

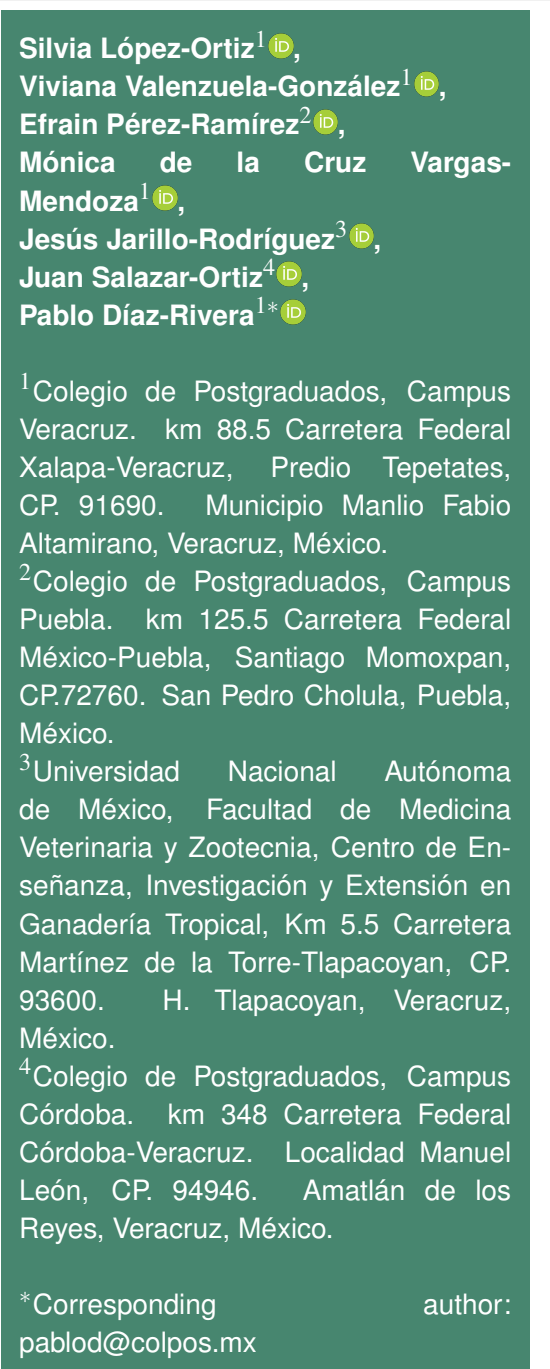

Scientific article

Received: March 05, 2021

Accepted: September 09, 2021

How to cite: López-Ortiz S Valenzuela-González V, PérezRamírez E, Vargas-Mendoza MC, Jarillo-Rodríguez J, Salazar-Ortiz J, Díaz-Rivera P (2021) Foraging behaviour and dry matter intake by lambs in a silvopastoral system. Ecosistemas y Recursos Agropecuarios Sp. Num II: e2913. DOI: 10.19136/era.a8nll.2913
ABSTRACT. Dry matter intake, nutritional contribution of forage to the diet and lamb foraging behavior were assessed in a silvopastoral system. Twelve Pelibuey female lambs (6.3 months of age, $23.74 \pm 3.5 \mathrm{~kg}$ live weight), were randomly assigned to two treatments: pastures of Digitaria eriantha (monoculture) or pastures of D. eriantha and Guazuma ulmifolia (silvopastoral). During a 15 day period, lambs foraged individually in $20.14 \mathrm{~m}^{2}$ paddocks each day; time spent grazing and browsing were assessed by scan sampling; dry matter intake was estimated (day 11-15), using the chromic oxide $\left(\mathrm{Cr}_{2} \mathrm{O}_{3}\right)$ method, and metabolizable energy (ME) and protein (CP) ingested by the lambs were estimated. Data analyses were performed using a complete randomized design (dry matter intake) and a repeated-measure design ( $\mathrm{ME}$ and $\mathrm{CP}$, foraging time) with factorial treatment structure of season (windy and dry) and pasture (monoculture and silvopastoral). Voluntary intake (season*treatment interaction, $p=0.015$ ) was lower in the windy-silvopastoral treatment $\left(448.5 \pm 38.2 \mathrm{~g} \mathrm{day}^{-1}\right)$ than in the other treatments $(625.8 \pm 38.2$ to $680.5 \pm 38.2 \mathrm{~g}$ day $\left.^{-1}\right)$. The contribution of ME (719.7-1190.2 kcal.day $\left.{ }^{-1}\right)$ and CP $\left(53.7-100.7 \mathrm{~g} \mathrm{day}^{-1}\right)$ was low to cover the lamb requirements in all treatments, because forage availability and dry matter intake were low. Lambs dedicated from $6.65 \pm 0.26$ to $7.50 \pm 0.26 \mathrm{~h}$ to foraging; time spent grazing was longer that browsing in the silvopastoral system $(p<0.0001)$. The time dedicated to foraging, intake, and nutritive quality of forage from in both pasture types did not provide sufficient nutrients and energy during any season for maintenance of the lambs.

Key words: Voluntary intake, tree-grass association, Pelibuey female lambs, energy, and protein consumption, Guazuma ulmifolia Lam.

RESUMEN. Se estimó el consumo de materia seca, calidad de dieta y comportamiento forrajero de corderas en un sistema silvopastoril. Se utilizaron 12 corderas Pelibuey (6.3 meses de edad y $23.74 \pm 3.5 \mathrm{~kg} \mathrm{PV}$ ), distribuidas en dos tratamientos: pradera de Digitaria eriantha (Monocultivo) y asociación $D$. eriantha-Guazuma ulmifolia (Silvopastoril). Durante 15 días, las corderas pastaron individualmente potreros de $20.14 \mathrm{~m}^{2}$ cada día, se evaluó el tiempo de pastoreo-ramoneo con un muestreo tipo escaneo; se estimó el consumo voluntario de materia seca (días 11-15) con el método oxido de cromo $\left(\mathrm{Cr}_{2} \mathrm{O}_{3}\right)$, y cuantificó la energía metabolizable (EM) y proteína (PC) ingeridos diariamente. Se utilizó un modelo completamente aleatorio (consumo de materia seca) y modelos de medidas repetidas (EM y PC, tiempo de forrajeo) con arreglo factorial de época (nortes y seca) y tipo de pastura (monocultivo y silvopastoril). El consumo voluntario difirió (interacción tratamiento*época, $\mathrm{p}=0.015)$, siendo menor en el tratamiento nortes-silvopastoril $\left(448.5 \pm 38.2 \mathrm{~g} \mathrm{día}^{-1} ; \mathrm{p}=\right.$ $0.019)$ que en los otros tratamientos $\left(625.8 \pm 38.2\right.$ a $\left.680.5 \pm 38.2 \mathrm{~g} \mathrm{día}^{-1}\right)$. La contribución de EM (719.7-1190.2 $\left.\mathrm{Kcal} \cdot d i ́ \mathrm{a}^{-1}\right)$ y PC (53.7-100.7 $\left.\mathrm{g}_{\text {día }}{ }^{-1}\right)$ a la dieta diaria no cubrió los requerimientos de las ovejas en ningún tratamiento por la baja disponibilidad y consumo de materia seca. Las corderas dedicaron de $6.65 \pm 0.26$ a $7.50 \pm 0.26 \mathrm{~h}$ al forrajeo; el tiempo de pastoreo fue más largo que el ramoneo en el sistema silvopastoril $(p<0.0001)$. El tiempo de forrajeo, consumo y calidad nutritiva del forraje en ningún tratamiento alcanzó a proveer los requerimientos de energía y proteína de las corderas.

Palabras clave: Consumo voluntario, asociación árbol gramínea, ovinos Pelibuey, consumo de energía y proteína, Guazuma ulmifolia Lam. 


\section{INTRODUCTION}

In tropical regions of the world, the primary forage-base for livestock are grasslands (Boval and Dixon 2012). In these regions, grass growth depends on natural seasonal precipitation that affects forage availability and quality throughout the year, limiting livestock performance and productivity (Giridhar and Samireddypalle 2015). Under proper management, fodder trees contribute to reducing forage shortages because they have phenology and growth habits different than grasses that allow them to grow during drought conditions when grasses become latent (Tamayo-Chim et al. 2012, Azuara-Morales et al. 2020). Furthermore, fodder trees provide nutrients that complement nutritional needs of grazing livestock (Lara et al. 2007). Despite the nutritive quality that fodder trees have, nutritional needs to achieve production goals might not be accomplished, because no forage has a perfect nutrient content to supply all needs for all animals. The nitrogen content of most fodder trees seems enough to sustain growth and high weight gains for meat production systems (Sosa et al. 2004, García and Medina 2006, BarrosRodríguez et al. 2012), but it depends on forage availability, nutritional quality of associated forage, dry matter intake and foraging time. The association of Digitaria eriantha Steud. cv. Pangola with the tropical tree Guazuma ulmifolia Lam. yields a productive silvopastoral system with good quality forage production under tropical conditions (Manríquez-Mendoza et al. 2011a, Ortega-Vargas et al. 2013), yet, information on the voluntary intake of dry matter, energy and nutrients, or foraging behavior, are not known. This data is particularly important when decisions regarding supplementation needs for small ruminants are needed. The objective of this research was to assess the intake of dry matter, energy, and nutrients as well as foraging behavior of female lambs in an intensive silvopastoral system composed of $D$. eriantha and G. ulmifolia during the windy and dry seasons in a tropical climate.

\section{MATERIALS AND METHODS}

\section{Experimental site}

The experiment was carried out in a region with a sub-humid warm climate classified as Aw1(w)(l')gw" (García 2004), where the mean annual temperature is $26.4{ }^{\circ} \mathrm{C}$ and the annual precipitation is less than 1060 $\mathrm{mm}$, with rainfall during summer (June to October).

\section{Seasons and experimental period}

This experiment assessed voluntary intake by female lambs during two seasons of the year. The first experimental period (December 27, 2011 to January 10,2012 ) took place during the windy season, when the mean ambient air temperature was $26.5^{\circ} \mathrm{C}$, rain was scarce and strong winds occur. The second experimental period (April 12 - 26, 2012) took place during the dry season, when the mean ambient air temperature was $37.1^{\circ} \mathrm{C}$, and air humidity was high. Climatic data was provided by a weather station (Model Pro2 ${ }^{\mathrm{TM}}$, Davis Instruments, California, USA) at Colegio de Postgraduados, Campus Veracruz (19 ${ }^{\circ}$ $1144 \mathrm{~N} ; 96^{\circ} 2013 \mathrm{~W}$ ).

\section{Animals and treatments}

Twelve Pelibuey female lambs, 6.3 months old and weighing $23.7 \pm 3.5 \mathrm{~kg}$ were examined. These female lambs were chosen to have similar age and body condition. Each lamb was randomly assigned to one of four treatment groups ( $n=6$ per group), combinations of season (windy and dry) and pasture type, $D$. eriantha (monoculture) and $D$. eriantha and G. ulmifolia (silvopastoral system or SPS).

\section{Paddocks and daily forage supply}

Each experimental pasture (monoculture and SPS) was $58 \mathrm{~m}$ long and $32 \mathrm{~m}$ wide and was divided into fifteen paddocks, one for each day of the experiment. Each day, one of these paddocks was subdivided into six sections $(3.8 \times 5.3 \mathrm{~m}$ equal to $20.14 \mathrm{~m}^{2}$ ) to allow one lamb to graze per section in each treatment. Forage allowance was calculated based on a preliminary measure of forage mass performed in the site. Prior to the experiment, the grass and trees were cropped sequentially in each of the 15 
paddocks over a 15-days period to provide 35-days regrowth for each day of the experiment; grass was cut to $10 \mathrm{~cm}$ stubble height, and trees were pruned to $1 \mathrm{~m}$ in height.

On each day of the experiment, available forage in the monoculture was assessed by cutting the grass to $5 \mathrm{~cm}$ above the ground in 10 quadrats $(50 \times 50 \mathrm{~cm})$ placed systematically along a transect through the pasture section for the day. In the silvopastoral system (SPS), the grass was sampled from six quadrats systematically placed along a transect transverse to the orientation of the tree edge to ensure a more representative sample from full sunlight and shaded areas. Tree fodder was assessed by clipping edible parts from six randomly chosen trees in the same section where the grass was sampled. Edible forage was composed of leaves, nonwoody stems, and twigs, simulating herbivory based on observations made in other studies (ManríquezMendoza et al. 2011b, Ortega-Vargas et al. 2013). Fodder available per tree was estimated and then multiplied by the total number of trees in the section for the day; after which total available forage was estimated including grass and tree biomass. Each day, a composite sample was separated from the biomass samples (grass and tree separated) to perform chemical analyses. The samples were oven dried at $60{ }^{\circ} \mathrm{C}$ for $48 \mathrm{~h}$, and then ground to $1 \mathrm{~mm}$ particle size using a Wiley Mill (Model TS3375E15, Thomas Scientific, New Jersey, USA).

\section{Adaptation period}

Before starting the experiment, lambs underwent a 10-day adaptation period to the experimental conditions. During that time, animals foraged from 07:00 to $18: 00 \mathrm{~h}$, with free access to water. Those lambs assigned to each treatment foraged together in the same paddock similar to the experimental paddocks.

\section{Experimental procedure}

The experimental period was 15-days during both seasons, during which lambs foraged individually in the $20.14 \mathrm{~m}^{2}$ paddocks previously designed. They stayed in the pastures $24 \mathrm{~h}$ per day and were moved to a new section at 09:00 $\mathrm{h}$ each day. Dry matter intake (kg DM lamb ${ }^{-1}$ day $^{-1}$ ) was assessed using chromic oxide $\left(\mathrm{Cr}_{2} \mathrm{O}_{3}\right)$ (Pond et al. 1989). Each animal was dosed with $1 \mathrm{~g} \mathrm{Cr}_{2} \mathrm{O}_{3}$ in hard jelly capsules No. 00 (Azteca Brand) at 07:00 h every day and feces were collected from the anus twice a day (08:00 and $14: 00 \mathrm{~h}$ ) during the last five days of the experimental period. At the end, a fecal composite sample was made from these samples for each lamb, from which a subsample was taken, oven dried at $80^{\circ} \mathrm{C}$ for $72 \mathrm{~h}$, then ground to a $1 \mathrm{~mm}$ particle size using a Wiley Mill (Model TS3375E15, Thomas Scientific, New Jersey, USA).

Chromic oxide in feces was measured using spectrophotometry (Model 80-2097-62, LKBUltraspec III Pharmacy, Cambridge, UK) at $440 \mathrm{~nm}$ after overnight-dry matter calcination at $450{ }^{\circ} \mathrm{C}$ (Fenton and Fenton, 1979). Fecal production (g DM day $^{-1}$ ) was estimated using Equation 1, then dry matter intake (voluntary intake) was calculated using the Equation 2 that includes the result from the Equation and the In vitro Dry Matter Digestibility (IVDMD) (Ramírez-Pérez et al. 2000).

$$
\begin{gathered}
\text { fecal production }((g D M) / \text { day })= \\
\frac{\text { Marker dose }(\mathrm{mg} / \text { day })}{\text { Concentration marker in feces }(\mathrm{mg} /(\mathrm{gDM}))} \\
\text { Voluntary Intake }((\mathrm{gDM}) / \text { day })= \\
\frac{\text { Fecal production }((\mathrm{gDM}) / \text { day })}{[1-(\text { IVDMD } / 100)]}
\end{gathered}
$$

Chemical analyses of the forage samples from the last five days of the experimental periods were performed, and these samples were collected on the same days as the fecal samples. Crude protein was estimated using the macro-Kjeldahl method (AOAC 1980); acid detergent fiber (ADF) and neutral detergent fiber (NDF) were estimated using ANKOM filter bags and the $\mathrm{ANKOM}^{200}$ in vitro digestion system (ANKOM Technology, New York, USA; ANKOM, 2010); lignin was measured using a $3 \mathrm{~L}$ Beaker with $72 \% \mathrm{H} 2 \mathrm{SO} 4$ and filter bags (AOAC 1997); and IVDMD was determined using ANKOM filter bags and 
a Daisy ${ }^{I I}$ incubator (ANKOM Technology, New York, USA; ANKOM, 2010). Metabolizable energy (ME) was estimated based upon Di Marco (2011):

\section{Metabolizable energy $=3.61 \times I V D M D$}

Time spent foraging (grazing and browsing) was recorded by scan sampling made at five-minute intervals (Solanki 2000). Observations were performed following all the lambs from each treatment in sequence. Each scan observation was converted to five-minute periods of time, then adding the time that each lamb spent performing each activity (Penning and Rutter 2004). Two trained observers performed the observations from 09:00 to 19:00 h. Observations started late in the morning due to $\mathrm{Cr}_{2} \mathrm{O}_{3}$ dosing, fecal sampling and fencing work that was needed to move lambs to a new paddock every day; observations ended at dusk when visibility was not sufficient to continue.

\section{Statistical analysis}

Forage availability, IVDMD, NDF, ADF, metabolizable energy and crude protein (CP) available to the lambs were assessed using descriptive statistics. Dry matter intake was analyzed using a completely randomized design with a factorial treatment structure of season (windy and dry) and two types of pasture (grass monoculture and silvopastoral system) for a total of four treatment combinations: windy-grass, windy-SPS, dry-grass and dry-SPS. The model included the effects of treatment, season, their interaction, and a random error term.

Foraging time, total intake of crude protein and energy were analyzed using a repeated-measure design with a factorial treatment structure of season and types of pasture, the models included the effects of treatment, season, day, all interactions, and a random error term. The model for foraging time used a Compound Symmetry (CS) covariance matrix assuming equal variances on all evaluation dates, and was chosen based on the fitted statistics for the model, while the model for total intake of crude protein and energy used a Toeplitz(1) covariance structure. A paired sample t-test was performed using the $t$-test procedure to test differences in the time spent grazing vs. browsing in the silvopastoral system; a separate test was performed for each season. All analyses were performed using the GLIMMIX procedure and the LSMeans method for mean comparisons in SAS (SAS 2013), except for the t-test.

\section{RESULTS}

\section{Forage availability and nutritive quality}

Available forage in the $20.14 \mathrm{~m}^{2}$ assigned to each lamb was 4.16 (grass monoculture) and 2.3 $\mathrm{kg} \mathrm{DM} \mathrm{day}^{-1}$ (silvopastoral) during the windy season, values lower than during the dry season (7.35 for the monoculture and $3.57 \mathrm{~kg} \mathrm{DM}$ day $^{-1}$ for the silvopastoral system). Digitaria eriantha forage had good nutritive quality between seasons, but declined slightly during the dry season, when crude protein decreased, and fiber components increased (Table 1). In the silvopastoral system, grass forage had lower crude protein than the grass monoculture. Tree forage quality was higher than for the grass, having less NDF, ADF and higher CP, while IVDMD was less than for the grass (Table 1).

\section{Dry matter intake}

Voluntary intake of dry matter ranged between 1.9 to $3.0 \%$ of LW equivalent to intakes from 448 to $680 \mathrm{~g} \mathrm{day}^{-1}$. Daily intakes varied as an effect of treatment by season interaction $(p=0.015)$; being greater in the windy-grass, dry-grass and dry-SPS treatments than in the windy-SPS treatment (Table 2).

\section{Foraging behavior}

Lambs spent from $6 \mathrm{~h} 39 \mathrm{~min}$ to $7 \mathrm{~h} 30 \mathrm{~min}$ foraging during the day (Table 3), and foraging took place only during the daylight hours (based on observations). There was an effect of day on foraging time $(p<0.0001)$, but not an effect from treatment ${ }^{\star}$ day $(p=$ $0.184)$ or season*day $(p=0.074)$; foraging by lambs throughout each day in each treatment depended on season $(p<0.001)$. This interaction denotes a more variable foraging behavior (foraging time) by lambs in the windy-SPS treatment, where foraging was less than in the other treatments during some days of the experimental period. In both seasons, lambs spent 
Table 1. Forage nutritive quality in a Digitaria eriantha monoculture and in a silvopastoral system containing Digitaria eriantha and Guazuma ulmifolia during the windy and dry seasons.

\begin{tabular}{|c|c|c|c|}
\hline \multirow[b]{2}{*}{ Variable } & \multirow{2}{*}{$\frac{\text { Grass Monoculture }}{\text { D. eriantha }}$} & \multicolumn{2}{|c|}{ Silvopastoral System } \\
\hline & & D. eriantha & G. ulmifolia \\
\hline & \multicolumn{3}{|c|}{ Windy .............. } \\
\hline NDF (\%) & $64.0 \pm 0.02$ & $65.0 \pm 0.02$ & $53.0 \pm 0.09$ \\
\hline $\operatorname{ADF}(\%)$ & $38.0 \pm 0.02$ & $40.0 \pm 0.02$ & $22.0 \pm 0.02$ \\
\hline CP (\%) & $16.1 \pm 1.24$ & $10.4 \pm 1.51$ & $14.0 \pm 1.35$ \\
\hline IVDMD (\%) & $48.0 \pm 0.03$ & $46.0 \pm 0.02$ & $44.0 \pm 0.05$ \\
\hline \multirow[t]{2}{*}{ ME (Mcal/kg DM) } & $1.7 \pm 0.12$ & $1.6 \pm 0.07$ & $1.6 \pm 0.17$ \\
\hline & \multicolumn{3}{|c|}{ 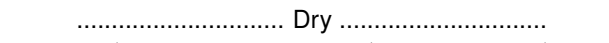 } \\
\hline NDF (\%) & $69.0 \pm 0.01$ & $68.0 \pm 0.01$ & $45.0 \pm 0.02$ \\
\hline $\operatorname{ADF}(\%)$ & $41.0 \pm 0.01$ & $40.0 \pm 0.01$ & $25.0 \pm 0.01$ \\
\hline $\mathrm{CP}(\%)$ & $8.4 \pm 0.83$ & $8.0 \pm 0.28$ & $15.2 \pm 1.76$ \\
\hline IVDMD (\%) & $50.0 \pm 0.02$ & $51.0 \pm 0.03$ & $36.0 \pm 0.01$ \\
\hline ME (Mcal/kg DM) & $1.8 \pm 0.06$ & $1.8 \pm 0.12$ & $1.3 \pm 0.05$ \\
\hline
\end{tabular}

more time grazing than browsing $(\mathrm{p}<0.0001)$ in the silvopastoral system (Table 3).

Table 2. Dry matter intake by lambs foraging in a grass monoculture (Digitaria eriantha) and in a silvopastoral system containing Digitaria eriantha and Guazuma ulmifolia.

\begin{tabular}{cccc}
\hline Treatment & $\mathrm{g} \mathrm{kg}^{-1} \mathrm{LW}^{0.75}$ & $\% \mathrm{LW}$ & $\mathrm{g} \mathrm{day}^{-1}$ \\
\hline Windy-grass & $54.2 \pm 3.3^{a}$ & $2.4^{a}$ & $625.8 \pm 38.2^{a}$ \\
Windy-SPS & $41.2 \pm 3.3^{b}$ & $1.9^{b}$ & $448.5 \pm 38.2^{b}$ \\
Dry-grass & $59.2 \pm 3.3^{a}$ & $3.0^{a}$ & $654.4 \pm 38.2^{a}$ \\
Dry-SPS & $60.2 \pm 3.3^{a}$ & $2.7^{a}$ & $680.5 \pm 38.2^{a}$ \\
\hline
\end{tabular}

Means with different superscript letters within a column are statistically different, $\alpha=0.05$; LW: Live weight; numbers after \pm are standard errors.

Table 3. Total time spent foraging, grazing, and browsing within a day, by lambs in a grass monoculture (Digitaria eriantha) and in a silvopastoral system containing Digitaria eriantha and Guazuma ulmifolia.

\begin{tabular}{ccc}
\hline Treatment & Time $(\mathrm{h})^{¥}$ & Time 00:00:00 (h:m:s) \\
\hline Windy-grass & $7.50 \pm 0.26^{a}$ & $07: 30: 00$ \\
Windy-SPS & $7.46 \pm 0.26^{a}$ & $07: 27: 06$ \\
Dry-gras & $7.05 \pm 0.26^{a}$ & $07: 03: 00$ \\
Dry-SPS & $6.65 \pm 0.26^{a}$ & $06: 39: 00$
\end{tabular}

Time grazing vs. browsing in the silvopastoral association $¥ ¥$

$\begin{array}{ccc} & \text { Grazing } & \text { Browsing } \\ \text { Windy } & 6.09 \pm 0.13^{a} & 1.37 \pm 0.13^{b} \\ \text { Dry } & 5.10 \pm 0.12^{a} & 1.55 \pm 0.12^{b}\end{array}$

$¥$ Means with different superscript letters within columns are statistically different, $\alpha=0.05$. ${ }^{¥}$ Comparisons were performed by season; means with different superscript letters within rows are statistically different, $\alpha=0.05$; numbers after \pm are standard errors.

\section{Pasture energy and nutrient supply}

Daily CP ingested by lambs differed among treatments $(p<0.05)$, being higher in windy-grass (100.7), intermedium in dry-SPS (75.1), and lowest in both dry-grass (56.2) and windy-SPS (53.7) (Table 4). The trees in the silvopastoral treatments provided 50 to $58 \%$ of the protein in the diet across seasons (data not shown in Table 4). Similar to the protein supply, lambs obtained more metabolizable energy from the windy-grass, dry-grass and dry-SPS treatments $\left(1190.2\right.$ to $\left.1081.2 \mathrm{kcal} \mathrm{day}^{-1}\right)$ than from the windy-SPS treatments $\left(719.7 \mathrm{kcal} \mathrm{day}^{-1}\right)(\mathrm{p}<$ $0.05)$. In the silvopastoral systems, the trees provided $292.4 \mathrm{kcal} \mathrm{day}^{-1}$ ( $40 \%$ of daily total supply) during the windy season and $371.9 \mathrm{kcal} \mathrm{day}^{-1}$ (33\% of daily total supply) during the dry season (data not shown in Table 4).

Table 4. Crude protein and energy supplied by the forage in a grass monoculture (Digitaria eriantha) and in a silvopastoral system containing Digitaria eriantha and Guazuma ulmifolia.

\begin{tabular}{lcc}
\hline Treatment & $\begin{array}{c}\text { Crude Protein } \\
\left(\mathrm{g} \cdot \mathrm{d}^{-1}\right)\end{array}$ & $\begin{array}{c}\text { Metabolizable Energy } \\
\left(\mathrm{kcal} \cdot \mathrm{d}^{-1}\right)\end{array}$ \\
\hline Windy-grass & $100.7 \pm 4.4^{a}$ & $1081.2 \pm 69.5^{a}$ \\
Windy-SPS & $53.7 \pm 4.4^{c}$ & $719.7 \pm 69.5^{b}$ \\
Dry-grass & $56.2 \pm 4.4^{c}$ & $1190.2 \pm 69.5^{a}$ \\
Dry-SPS & $75.1 \pm 4.4^{b}$ & $1103.6 \pm 69.5^{a}$ \\
\hline
\end{tabular}




\section{DISCUSSION}

Lower dry matter availability during the windy season is a plant response to seasonality when they become latent. Low yield has been reported (Manríquez-Mendoza et al. 2011b) in the same site during the windy season. The availability of forage in the silvopastoral system was low during both seasons compared with the grass monoculture. Here, pasture management caused variable forage biomass between the pastures because the grass monoculture was a new pasture established immediately prior to starting the experiment in a site that had been at rest for 4 years. Previous accumulation of organic matter favored greater yield in that pasture over the silvopastoral system. The daily forage allowance was enough to fulfill individual lamb dry matter needs, except in the silvopastoral pasture during the windy season, while fodder trees provided a minor proportion, $8.2(0.188 \mathrm{~kg} \mathrm{DM})$ and $7.9 \%(0.283 \mathrm{~kg} \mathrm{DM})$ of total forage biomass during the windy and dry seasons, respectively. This fodder contribution is low for what is needed from trees to complement ruminant diets (Villanueva-Partida et al. 2019).

A tendency for declining nutritive quality of grass in the dry season was observed in both the monoculture and the silvopastoral system. In the present research, forage nutritive value in the grass monoculture was high for a grass (Juárez et al. 2009), favored because it was a new pasture (Perales et al. 2009) established in a nutrient-rich site. Forage quality declined during the dry season as a response to more rapid growth and grass maturity that negatively affected forage quality (Villalobos and Sánchez 2010, Manríquez-Mendoza et al. 2011b). Indicators of nutritive quality for the tree are higher than for the grass, but with a lower IVDMD due to the presence of phenolic compounds bound to cell walls and proteins (Carmona 2007). This binding is known to reduce dry matter digestibility (Emmans 1991), but it should not negatively affect dry matter intake or animal performance when concentrations are low (Alves et al. 2017, Méndez-Ortiz et al. 2018). The nutrient content in G. ulmifolia was close to values reported by Pezo et al. (1990) and Flores et al. (1998).
Dry matter intake was low to normal for the type of animals examined in this experiment, although intakes are lower than those from other reports. For example, Mayren-Mendoza (2018) supplemented lambs (at the same weight and age) with G. ulmifolia fodder, and observed a $20 \%$ increase in daily dry matter intake when tree fodder was offered at $50 \%$ of total DM daily requirements. As a consequence, feed conversion and performance improved. Similarly, crossbred lambs weighing $13 \mathrm{~kg}$ ingested from 2.9 to $3.2 \%$ LW when fed fodder from five tree species at different supplementation levels (Sosa et al. 2004). However, as voluntary intake depends on several internal and external conditions, other authors have reported even higher intakes. González-Garduño et al. (2011) recorded from 710 to $790 \mathrm{~g} \mathrm{DM} \mathrm{day}^{-1}$ in lambs of the same age as those in this experiment when fed Pennisetum purpureum and other sources of protein. Nahed et al. (2011) recorded $868 \mathrm{~g} \mathrm{DM}$ day $^{-1}$ in creole lambs fed Buddleia skutchii fodder as a supplement.

We expected that lambs in the silvopastoral system had greater or similar intakes to those grazing in the monoculture, but this did not occur in our experiment during the windy season. The reason was the lower forage availability in the silvopastoral system during the windy season that was roughly half the amount in the monoculture. Availability of forage directly affects intake (Reinoso and Soto 2006), and the reason for this forage shortage was the climate seasonality that limited availability not only in the silvopastoral system, but also in the monoculture pasture. During the dry season, intakes were higher, and even though less forage was available in the silvopastoral system, lambs made better forage utilization than those in the monoculture.

Greater foraging time during the season of lower forage availability (as in this experiment) and the lower dry matter intake might indicate a smaller bite size (Galli and Cangiano 1998), increasing the time for harvesting food. This situation was more evident in the silvopastoral system where intake was lower during the windy season. Conversely, during the dry season, when there was more forage available in both systems, intake became equal between treatments 
even though total foraging time declined slightly. It is possible, that time spent foraging declined during the dry season due to high temperatures (Forbes 2007), since searching for food was performed during the hotter hours of the day (09:00 to 19:00 h). Prior to this time, when the first feeding bout takes place (Forbes 2007), animals were being manipulated due to experimental procedures. However, they might have compensated for this by feeding during dusk and night hours (Arias et al. 2008).

Climate conditions during the dry and windy seasons in the area where this experiment was performed are different (García 2004). During the dry season there is greater solar radiation and higher temperatures, hence the lambs in the silvopastoral system spent more time laying down under large shrubs/trees, protected from the sun rather than foraging (data not shown). However, their intake was equal to those lambs in the grass monoculture, probably due to a higher nutrient content in the forage (Table 1). Lambs in the grass monoculture had little shade to protect them from the sun, thus they spent more time foraging, standing and panting.

Less time browsing suggests low tree fodder availability during both seasons, as was evident during the experiment where fodder was first to disappear from the pastures. Across the experiment, trees contributed no more than $10 \%$ of total forage available. Solórzano-Montilla et al. (2018) observed West African lambs from 08:00 to 15:00 $\mathrm{h}$ in pastures provided with artificial shade during the rainy season and reported that those animals having shade spent more time grazing.

According to our results, if shade is available, animals will spend more time resting, leading to shorter foraging times. Although no comparable reports of this behavior in lambs were found, Kendall et al. (2006) observed that dairy cows, when presented with artificial shade, spent the hotter part of the day in the shade, while cows without shade foraged for some time during those hours. As well, Améndola et al. (2019) observed heifers had longer foraging times in a grass monoculture than in an intensive silvopastoral system. These reports suggest that available shade in pastures (whether it is in silvopastoral systems or not) promotes resting during the hotter hours of the day to regulate body temperature (Kendall et al. 2006, Schütz et al. 2009, Améndola et al. 2019), apparently reducing foraging time, but this loss may be replaced during other times of the day. Cattle in a monoculture system, however, spent more time searching for food and foraging at times of the day when temperatures were higher, as a compensatory strategy (Améndola et al. 2019).

Given the forage available in the paddocks, crude protein supplied by both treatments during both seasons was low, similar to systems based only on grasses as a forage source (Alonso 2011). Thus, the quantity of $\mathrm{CP}$ in the diet was below the requirements for this livestock breed, given their weight and physiological state. The growing lambs examined in this experiment should have ingested about $2.4 \mathrm{~g}$ $\mathrm{kg}^{-1} \mathrm{LW}^{0.75}$ day $^{-1}$ for maintenance (INRA 1978). Accordingly, the Agricultural and Food Research Council (AFRC 1993) establishes $75.1 \mathrm{~g} \mathrm{CP}$ and 2.04 Mcal day ${ }^{-1}$ for a $25 \mathrm{~kg} \mathrm{LW}$ in order to gain $100 \mathrm{~g}$ day $^{-1}$. Crude protein in the diet was low compared to that in the diet of livestock foraging other pastures having legume trees such as Leucaena leucocephala, which can contain up to 30\% CP (Dávila et al. 1997, Sosa et al. 2004). In comparison, G. ulmifolia as a non-leguminous tree, contains up to $18-20 \% \mathrm{CP}$ (Manríquez-Mendoza et al. 2011a, Ortega-Vargas et al. 2013). Energy supply also was low in both treatments and seasons compared to that recommended by Chay-Canul et al. (2016) for Pelibuey lambs (2.0 Mcal day ${ }^{-1}$ ) weighing $25 \mathrm{~kg} \mathrm{LW}$ and gaining $50 \mathrm{~g}$ day $^{-1}$. Thus, fodder tree dry matter offered in this silvopastoral system would have to increase to a higher nutrient supply, or a supplementation strategy must be considered. Forage nutritive value was assessed from samples clipped $5 \mathrm{~cm}$ above the ground, but the nutrient content of these samples might differ from the actual nutrient intake because sheep are selective and might have chosen more digestible forage (Caja 2001). Given the low availability of forage, it is likely that true energy and nutrient intake differed from that estimated for the examined samples. 


\section{CONCLUSIONS}

Given the limitations on forage availability, voluntary intake in the silvopastoral system with $D$. eriantha and G. ulmifolia was low and depended on season. Intake was higher during the dry season when forage availability increased, and less time was spent foraging. Energy and crude protein supply also were restrictive, but given the nutritious quality of the tree fodder, this restriction might be overcome by increasing forage allowance during times of forage shortage by increasing tree density in pastures to increase fodder and nutrient supply in the system.

\section{LITERATURE CITED}

AFRC (1993) Agricultural and Food Research Council. Energy and protein requirements of ruminants. Commonwealth Agricultural Bureau International. Wallingford, UK. 159p.

Alonso J (2011) Los sistemas silvopastoriles y su contribución al ambiente. Revista Cubana de Ciencia Agrícola 45: $107-115$.

Alves TP, Dall-Orsoletta AC, Ribeiro-Filho HMN (2017) The effects of supplementing Acacia mearnsii tannin extract on dairy cow dry matter intake, milk production, and methane emission in a tropical pasture. Tropical Animal Health and Production 49: 1663-1668.

Améndola L, Solorio FJ, Ku-Vera JC, Améndola-Massioti RD, Zarza H (2019) A pilot study on the foraging behavior of heifers in intensive silvopastoral and monoculture systems in the tropics. Animal 13: 606-616.

ANKOM (2010) ANKOM Technology Instrument Manuals. http://www.ankom.com/instrument-manuals.aspx. Data consulted: february 12, 2012.

AOAC (1980) Official Method 4.2.11 Protein (crude) in animal feeds, forage (plant tissue) grain and oilseeds. In: Official Methods of Analysis of AOAC International. 13th edition. AOAC International. Washington D.C., USA. pp. 125-129.

AOAC (1997) Official Method 973.18. Fiber (acid detergent) and lignin in animal feed. In: Official Methods of Analysis of AOAC International, 16th edition. AOAC International, Washington D.C., USA. pp. 28-29.

Arias RA, Mader TL, Escobar PC (2008) Factores climáticos que afectan el desempeño productivo del ganado bovino de carne y leche. Medicina Veterinaria 40: 7-22.

Azuara-Morales I, López-Ortiz S, Jarillo-Rodríguez J, Pérez-Hernández P, Ortega-Jiménez E, Castillo-Gallegos E (2020) Forage availability in a silvopastoral system having different densities of Leucaena leucocephala under Voisin grazing management. Agroforestry Systems 94: 1701-1711.

Barros-Rodríguez M, Solorio-Sánchez J, Ku-Vera J, Ayala-Burgos A, Sandoval-Castro C, Solís-Pérez G (2012) Productive performance and urinary excretion of mimosine metabolites by hair sheep grazing in a silvopastoral system with high densities of Leucaena leucocephala. Tropical Animal Health and Production 44: 1873-1878.

Boval M, Dixon RM (2012) The importance of grasslands for animal production and other functions: a review on management and methodological progress in the tropics. Animal 6: 748-762.

Caja G (2001) Orientaciones básicas para la alimentación del ganado ovino de carne. Producció Ovina i Caprina. Facultat de Veterinaria. UAB. 10p.

Carmona, AJC (2007) Efecto de la utilización de arbóreas y arbustivas forrajeras sobre la dinámica digestiva en bovinos. Revista Lasallista de Investigación 4: 40-50. 
Chay-Canul AJ, Magaña-Monforte JG, Chizzottic ML, Piñeiro-Vázquez AT, Canul-Solís JR, Ayala-Burgos AJ, KuVera JC, Tedeschie LO (2016) Energy requirements of hair sheep in the tropical regions of Latin America. Review. Revista Mexicana Ciencias Pecuarias 7: 105-125.

Dávila C, Urbano D, Sánchez R (1997) NR. 14. Efecto de la asociación Brachiaria sp. con Leucaena (Leucaena leucocephala) y matarratón (Gliricidia sepium) sobre la producción de leche. Archivo Latinoamericano de Producción Animal 5: 135-138.

Di Marco O (2011) Estimación de calidad de los forrajes. Sitio Argentino de Producción Animal 20: 24-30.

Emmans GC (1991) Diet selection by animals: Theory and experimental designs. Proceeding of the Nutrition Society 50: 59-64.

Fenton TW, Fenton M (1979) An improved procedure for the determination of chromic oxide in feed and feces. Canadian Journal of Animal Science 59: 631-634.

Flores OI, Bolivar DM, Botero JA, Ibrahim MA (1998) Parámetros nutricionales de algunas arbóreas leguminosas y no leguminosas con potencial forrajero para la suplementación de rumiantes en el trópico. Livestock Research for Rural Development 10: 1-5.

Forbes MJ (2007) Voluntary food intake and diet selection in farm animals. 2nd ed. CABI. London UK. 453p.

Galli JR, Cangiano CA (1998) Relación entre la estructura de la pastura y las dimensiones del bocado y sus implicancias en el consumo en bovinos. Revista Argentina de Producción Animal 18: 247-261.

García E (2004) Modificaciones al sistema de clasificación climática de Köppen. 5a. Ed. Instituto de Geografía. UNAM. México. 97p.

García DE, Medina MG (2006) Composición química, metabolitos secundarios, valor nutritivo y aceptabilidad relativa de diez árboles forrajeros. Zootecnia Tropical 24: 233-250.

Giridhar K, Samireddypalle A (2015) Impact of climate change on forage availability for livestock. In: Sejian V, Gaughan J, Baumgard L, Prasad C (eds) Climate change Impact on Livestock: Adaptation and Mitigation. Springer, New Delhi. pp: 97-112.

González-Garduño R, Torres-Hernández G, Arece-García J (2011) Ganancia de peso de ovinos alimentados con pasto Taiwan (Pennisetum purpureum) suplementados con diversas fuentes de proteína. Avances de Investigación Agropecuaria 15: 3-20.

INRA (1978) Institut Nacional the Recherche Agronomique. Ovins. In: Alimentation des Ruminants. Ed. INRA Publications. Route Saint Cyr. 78000. Versailles, France. 403p.

Juárez RAS, Cerrillo SMA, Gutiérrez OE, Romero TEM, Colín NJ, Bernal BH (2009) Estimación del valor nutricional de pastos tropicales a partir de análisis convencionales y de la producción de gas in vitro. Revista Técnica Pecuaria en México 47: 55-67.

Kendall PE, Nielsen PP, Webster JR, Verkerk GA, Littlejohn RP, Matthews LR (2006) The effects of providing shade to lactating dairy cows in a temperate climate. Livestock Science 103: 148-157.

Lara PE, Canché MC, Marrufo NB, Sanginés JR (2007). Pastoreo restringido de ovejas Pelibuey en bancos de proteína de morera (Morus alba). Pastos y Forrajes 30: 267-278.

Manríquez-Mendoza LY, López-Ortíz S, Pérez-Hernández P, Ortega-Jiménez E, López-Tecpoyotl ZG (2011a) Agronomic and forage characteristics of Guazuma ulmifolia Lam. Tropical and Subtropical Agroecosystems 14: 453-463. 
Manríquez-Mendoza LY, López-Ortíz S, Olguín-Palacios C, Pérez-Hernández P, Díaz-Rivera P, López-Tecpoyotl, ZG (2011b) Productividad de un sistema silvopastoril intensivo. Tropical and Subtropical Agroecosystems 13: $573-584$.

Mayren-Mendoza FJ, Rojas-García AR, Maldonado-Peralta MA, Ramírez-Reynoso O, Herrera-Pérez J, TorresSalado N, Sánchez-Santillán P, Bottini-Luzardo MB, Hernández-Garay A (2018) Comportamiento productivo de ovinos Pelibuey en pastoreo suplementados con follaje de Guazuma ulmifolia Lam. Agroproductividad 11: 29-33.

Méndez-Ortiz FA, Sandoval-Castro CA, Ventura-Cordero J, Sarmiento-Franco LA, Torres-Acosta JFJ (2018) Condensed tannin intake and sheep performance: A meta-analysis on voluntary intake and live weight change. Animal Feed Science and Technology 245: 67-76.

Nahed TJ, Solís EC, Grande CD, Mendoza MG, Alayón GJA, Pérez-Gil RF (2011) Comportamiento productivo de ovinos alimentados con pasto kikuyo Pennisetum clandestinum y follaje de Tzelopat Buddleia skutchii. FAO. 10p.

Ortega-Vargas E, López-Ortiz S, Burgueño-Ferreira JA, Campbell WB, Jarillo-Rodríguez J (2013) Date of pruning of Guazuma ulmifolia during the rainy season affects the availability, productivity and nutritional quality of forage during the dry season. Agroforestry Systems 87: 917-927.

Penning PD, Rutter SM (2004) Ingestive behavior. In: Penning PD (ed.) 2nd Ed. Herb Intake. Handbook. British Grassland Society. pp: 151-175.

Perales A, Loli O, Alegre J, Camarena F (2009) Indicadores de sustentabilidad del manejo de suelo en la producción de arveja (Pisum sativum L.). Ecología Aplicada 8: 47-52.

Pezo D, Kass M, Benavides J, Romero F, Chaves C (1990) Potential of legume tree fodder as animal feed in Central America. In: Devendra C (ed.) Shrub and tree fodders for farm animals, Proceedings of a Workshop in Denpasar, Indonesia. IDRC. Ottawa, Canada. pp. 163-175.

Pond KR, Ellis WC, Matis JH, Deswysen AG (1989) Passage of chromium-mordanted and rare-earth-labeled fiber: time dosing kinetics. Journal of Animal Science 67: 1020-1028.

Ramírez-Pérez AH, Buntinx SE, Tapia-Rodríguez C, Rosiles R (2000) Effect of breed and age on the voluntary intake and the micromineral status of non-pregnant sheep. 1. Estimation of voluntary intake. Small Ruminant Research 37: 223-229.

Reinoso OV, Soto SC (2006) Cálculo y manejo en pastoreo controlado. 1) Nivel de oferta forrajera y utilización de la pastura. Revista Veterinaria Montevideo 41: 9-14.

SAS (2013) SAS/STAT 13.1. User's Guide The GLIMMIX Procedure. The SAS Institute Inc. Cary. N.C., USA. 3080-3432.

Schütz AK, Rogers RA, Cox RN, Tucker BC (2009) Dairy cows prefer shade that offers greater protection against solar radiation in summer: Shade use, behavior and body temperature. Applied Animal Behavior Science 116: $28-34$.

Solanki GS (2000) Grazing behaviour and foraging strategy of goats in semi-arid region in India. Tropical Ecology 41: 155-159.

Solórzano-Montilla J, Pinto-Santini L, Camacaro-Calvete S, Vargas-Guzmán D, Ríos L (2018) Effect of the presence of shade in sheep grazing areas. 2 Actividad Animal. Pastos y Forrajes 41: 41-49.

Sosa REE, Pérez RD, Ortega RL, Zapata BG (2004) Evaluación de potencial forrajero de árboles y arbustos tropicales para la alimentación de ovinos. Revista Mexicana de Ciencias Pecuarias 42: 129-144. 
Tamayo-Chim M, Reyes-García C, Orellana, R (2012) A combination of forage species with different responses to drought can increase year-round productivity in seasonally dry silvopastoral systems. Agroforestry Systems 84: 287-297.

Villalobos L, Sánchez JMI (2010) Evaluación agronómica y nutricional del pasto ryegrass perenne tetraploide (Lolium perenne) producido en lecherías de las zonas altas de Costa Rica. II. Valor nutricional. Agronomía Costarricense 34: 43-52.

Villanueva-Partida CR, Díaz-Echeverría VF, Chay-Canúl AJ, Ramírez-Avilés L, Casanova-Lugo F, Oros-Ortega I (2019) Productive and ingestive behavior in growing hair sheep in silvopastoral and stabled weight gain system. Revista Mexicana Ciencias Pecuarias 10: 870-884. 